$\begin{array}{cc}\text { Tür Coğrafya Dergisi } & \text { Turkish Geographical Review } \\ \text { Basıli ISSN 1302-5856 } & \text { ww.tcd.org.tr }\end{array}$

\title{
Kümeleme analizi ile Türkiye’nin biyoiklim bölgelerinin sınıflandırılması
}

\section{Classification of Turkey's bioclimatic regions by cluster analysis}

\author{
Fazilet Atasoy a (D) Faize Sarış *b \\ ${ }^{a}$ Çanakkale Onsekiz Mart Üniversitesi, Sosyal Bilimler Enstitüsü, Çanakkale, Türkiye. \\ ${ }^{b}$ Çanakkale Onsekiz Mart Üniversitesi, Fen-Edebiyat Fakültesi, Coğrafya Bölümü, Çanakkale, Türkiye.
}

ORCID: F. A. 0000-0001-8790-8772; F. S. 0000-0002-1721-4959

\section{BILGI / INFO}

Geliş/Received: 04.12.2020

Kabul/Accepted: 07.04.2021

\section{Anahtar Kelimeler:}

Biyoiklim indisleri

Sıcaklık

Yağış

Kümeleme analizi

Vejetasyon

\section{Keywords:}

Bioclimatic indices

Temperature

Precipitation

Cluster analysis

Vegetation

*Sorumlu yazar/Corresponding author:

(F. Sarış) faizesaris@gmail.com

DOI: $10.17211 /$ tcd. 835964

\section{Athf/Citation:}

Atasoy, F., \& Sarış, F. (2021). Kümeleme analizi ile Türkiye'nin biyoiklim bölgelerinin sınıflandırılması. Türk Coğrafya Dergisi, (77), 67-76.

https://doi.org/10.17211/tcd.835964

\section{ÖZ / ABSTRACT}

Bu çalışmanın amacı, Türkiye için kümeleme analizi aracılı̆̆ıyla biyoiklim sınıflandırması yaparak biyoiklim karakterini tanımlamak ve bölgesel farklılaşmayı açıklamaktır. Türkiye için biyoiklim indislerinin mekansal analizi, Devlet Meteoroloji İşleri Genel Müdürlüğü’ne ait toplam 169 istasyonda 1960-2016 yılları arasında kaydedilen aylık sıcaklık ve yağış verileri kullanılarak gerçekleştirildi. Kümeleme analizi için Biyoiklim değişkenleri 3 farklı veri seti halinde kullanıldı. Sıcaklık baskın değişkenlerin (BIO1-BIO11) kümeleme analizi sonucunda 4, yağış baskın değişkenler (BIO12-BIO19) için 5, tüm değişkenlerin bir arada değerlendirildiği analizde (BIO1-BIO19) 6 küme tanımlandı. BIO1BIO19 analizi sonucunda elde edilen kümelerin özellikleri: temel olarak yüksek sıcaklıkla karakterize olan ve Ege- Akdeniz kıyı kuşağı boyunca yayılan Küme 1; Kuraklık ve görece yüksek soğuk mevsim sıcaklıkları ile öne çıkan ve güneydoğuda dağılış gösteren Küme 2; soğuk karakter ile tanımlanan kuzeydoğu-doğu kesimlerdeki Küme 3; yine kuraklıkla tanımlanan ama daha soğuk kış karakterinde olan, iç bölgelerde geniş alana yayılmış ve en fazla istasyon sayısına sahip Küme 4; Marmara Bölgesi sınırlarında dağılışa sahip, biyoiklim karakteri olarak da Karasal (küme 4) ve nemli (Küme 6) arasında geçiş gösteren Küme 5 ve son olarak da nemlilik özelliği ile karakterize edilebilen ve Karadeniz kıyı kuşağı boyunca dağııı̧ sergileyen Küme 6 olarak tanımlandı. Belirlenen örüntüler ve biyoiklim karakteristikleri bölgeselleşme üzerinde topografya ve iklimin ortak etkisini açıkça göstermektedir.

The aim of this study is undertaking a bioclimatic classification through cluster analysis for Turkey to define the bioclimatic character and explain regional differentiation. Spatial analysis of bioclimatic indices for Turkey was performed by using monthly records of temperature and precipitation totals for the period 1960-2016 at 169 stations of the Turkish State Meteorological Service. Bioclimatic variables were assessed in three different data sets for cluster analysis. For temperature dominant variables (BIO1-BIO11) four clusters; for precipitation dominant variables (BIO12-BIO19) five clusters and for all indices (BIO1-BIO19) six clusters were defined as a result of the analysis. Characteristics of clusters identified for BIO1-BIO19 indices can be summarised as: Cluster 1 is characterized basically by high temperature and spread along the Aegean-Mediterranean coastal belt (28 stations). Cluster 2 stands out with dry and relatively high temperatures in the cold season and shows the distribution in the southeast Anatolia (35 stations). Cluster 3 spreads over the northeast-east sections and defined by cold character (9 stations). Cluster 4 is also defined by dry conditions but has a colder winter character, predominates in wide areas of the inner regions and represented by the highest number of stations (53 stations). Cluster 5 roughly encompasses the Marmara Region and has a transitional character between continental (Cluster 4) and humid (Cluster 6) (29 stations), and finally Cluster 6 which can be defined by humid character and observed along the Black Sea coastal belt (15 stations). The determined patterns and bioclimatic characteristics clearly show the common effect of topography and climate on the regionalisation. 
Extended Abstract Introduction

Bioclimatology studies the relationship between atmosphere and biosphere, more specifically examining the effects of climate on living organisms in various time and space scales. $\mathrm{Bi}-$ oclimate concerns all living things developing in a large number of ecosystems in the biosphere and basically has a close relationship with plant, animal and human ecology. Bioclimatology research efforts concentrate on the climate effects on plant species diversity and distribution in any region, thus contribute to the understanding of the living environments and distribution of living things. At this point, climate classifications are an important tool. Conventional classification methods such as Köppen-Geiger, De Martonne, Thornthwaite have been widely applied at different spatial scales. Recently, new classification approaches mostly based on indices become applicable. Multivariate statistics techniques (factor, principal components and cluster analysis etc.) examine several number of sub-variables together instead of a limited number of parameters, hence these techniques have been increasingly evaluating for bioclimatic classification. Turkey's geographical location and topographic variability (especially elevation and aspect) create important discrepancies in climatic conditions. This complex character both in topography and climate leads to significant diversity in the vegetation, which places Anatolia among the rich floristic areas over the World. This study aims to undertake a bioclimatic classification for Turkey through cluster analysis and identify regional differentiation of bioclimatic characteristics. The typology of the determined bioclimatic regions was explained through index definitions and dominant forest types.

\section{Data and Method}

Spatial analysis of bioclimatic indices for Turkey was performed by using monthly records of mean, maximum, minimum temperature and precipitation totals for the 57 years period (between the years 1960-2016) at 169 stations of the Turkish State Meteorological Service. Optimum temporal and spatial resolution was evaluated for achieving a comprehensive illustration of variability patterns. Bioclimatic indices developed by USA Geological Survey emphasizing the climatic conditions best associated with species physiology were adopted. Bioclimatic variables include annual trends (average annual temperature, annual precipitation), seasonality (annual range in temperature and precipitation area) and extreme or limiting environmental factors (temperature of the coldest and warmest month, wet and dry quarters). Clustering Analysis Ward's method was used for classification.

\section{Results and Discussion}

Bioclimatic variables were assessed in three different data sets for cluster analysis. For temperature dominant variables (BIO1-BIO11) four clusters; for precipitation dominant variables (BIO12-BIO19) five clusters and for all indices (BIO1-BIO19) six clusters were defined as a result of the analysis. In temperature based index classification; the first cluster was distributed to the northern and southern coasts, the second cluster in Southeast Anatolia, the third cluster in Eastern Anatolia, the fourth cluster in Central Anatolia and Marmara Region. Precipitation dominant classification shows more variable pattern.
The first cluster is distributed in the Aegean, Mediterranean coasts and Southeastern Anatolia Region; the second cluster is widely distributed in the interior; the third cluster is in a small region in the Mediterranean Region where Kaş, Antalya, Alanya and Gazipaşa stations are located; the fourth cluster pervades along the Black Sea Coastal Region and the Marmara, and the fifth cluster is represented by Rize and Hopa stations where located on northeastern Black Sea Coast. Characteristics of clusters identified for BIO1-BIO19 indices can be summarised as : Cluster 1 is characterized basically by high temperature and spread along the Aegean-Mediterranean coastal belt ( 28 stations). Cluster 2 stands out with dry and relatively high temperatures in cold season and shows distribution in the southeast Anatolia (35 stations). Cluster 3 spreads over the northeast-east sections and defined by cold character ( 9 stations). Cluster 4 is also defined by dry conditions but has a colder winter character, predominates in wide areas of the inner regions and represented by highest number of stations (53 stations). Cluster 5 roughly encompasses the Marmara Region and has a transition character between continental (Cluster 4) and humid (Cluster 6) (29 stations), and finally Cluster 6 which can be defined by humid character and observed along the Black Sea coastal belt (15 stations). The determined patterns and bioclimatic characteristics clearly show the common effect of topography and climate on the regionalisation. Additionally, the spatial distribution of the bioclimatic indices (BIO1-19) is highly compatible with the spatial variability pattern of various classifications determined in previous studies. The study can serve as a basis for future bioclimatic classification studies, since the index-based studies should be amplified by increasing inputs representing other driving factors such as soil, altitude, humidity, etc.. Especially when considering the rapidly changing climate and land cover change in Turkey; Analyzing the vegetation-climate relationship is very important in determining hot spots and understanding pressures on ecosystems.

\section{Giriş}

Biyoklimatoloji, çeşitli zaman ve mekan ölçeklerinde atmosfer ile biyosfer arasındaki ilişkiyi; iklimin canlı organizmalar üzerindeki etkilerini inceleyen bir çalışma alanıdır. Biyoiklim, biyosferde çok sayıdaki ekosistemlerde gelişen bütün canlıları ilgilendirir ve temel olarak bitki, hayvan ve insan ekolojisi ile sıkı bir ilişkisi vardır (Akman,1990). Biyoiklim çalışmalarının tarihsel süreçteki gelişimine bakıldığında, canlıların yaşam ortamlarını ve dağılışlarını belirlemek için ele alındığı ve özellikle herhangi bir bölgedeki bitki türü çeşitliliği ve dağılışı üzerindeki iklim etkilerinin ortaya konulduğu ifade edilebilir (Atasoy, 2018). Bu noktada iklim sınıflandırmaları önemli bir araçtır. İklim sınıflandırmaları ile yeryüzünde önemli iklim bölgeleri ve bu iklim bölgelerinde gelişen biyolojik yaşam ilişkilendirilir. Bu iklim sınıflandırmalarından en önemlileri; Köppen-Geiger, De Martonne, Emberger ve Thornthwaite gibi yöntemleridir. Bu sınıflandırmalara ek olarak Faktör, Asal Bileşenler ve Kümeleme analizi gibi yöntemlerin geliştirilmesiyle, çok daha yüksek çözünürlüklü ve kapsamlı veri setleri kullanılmaya başlanmışthr (Orlov \& Sheludkov, 2019). Biyoiklim indis analizleri olarak genel bir başlıkta değerlendirilebilecek bu çalışmaların erken örneklerinden biri, Kanada genelindeki 74 bitki örtüsü bölgesi arasındaki biyoklimatik ilişkileri incelemek amacıyla gerçekleştirilmiştir (Miller, 1973). Miller, çok değişkenli bir model geliş- 
tirebilmek için 11 özet iklim özniteliği verisi kullanarak faktör analizi uygulamıştır. Maksimum sıcaklık, minimum sıcaklık, bağıl nem, rüzgar hızı gibi parametreleri kullanarak, asal bileşenler ve kümeleme analizleri ile $A B D$ ve Kanada için yapılan biyoiklim sınıflandırması çok değişkenli analizler açısından örnek çalışmalardan bir diğeridir (DeGaetano \& Schulman, 1990). Şili için gerçekleştirilen bir başka çalışmada, temelde sıcaklık ve yağış rejimine dayanan bir yaklaşımla orman topluluklarının biyoiklim özellikleri sınıflandırımıştır (Amigo \& Ramirez, 1998). 2000'li yıllarla birlikte biyoiklim sınıflandırması çalışmalarında hem tür odaklı yaklaşımlar, hem de iklim değişikliğinin etkilerini anlamaya yönelik model çalışmaları görünür olmaya başlamıştır. Pearson ve Dawson (2003) iklim değişikliğinin türlerin doğal dağılımı üzerindeki potansiyel etkilerini tahmin etmek için biyoiklim karakteristiğe dayanan modelleme stratejileri üzerine odaklanmıştrr. Vogel vd. (2005) iklimsel değişkenliğine karşı bitki uyum bölgelerini belirlemek için gerçekleştirdikleri çalışmada genel adaptasyon alanlarının sınıflandırması yapmışlardır. İran'ın İsfahan bölgesi için gerçekleştirilen bir başka çalışmada ise, Yagmaei vd. (2009) bitki ekolojik koşullarında daha önemli olan iklim değişkenlerini seçerek; çok değişkenli istatistiksel yöntem kullanarak İsfahan ilindeki biyoklimatik bölgeleri belirlemişlerdir. İsfahan için yedi biyoiklim bölgesi tespit edilmiştir. Pesaresi vd. (2014), kaynak veri olarak WorldClim yağış ve sıcaklık veri kümesini kullanarak, İtalya bölgesi için bioklimatik teşhis ve ulusal ölçekte vejetasyon-çevre ilişkisi modellemesini ortaya koymutur. Rodriguez vd. (2014) ise, doğal potansiyel vejetasyonunun fizyonomik ve floristik özelliklerine odaklanan bir biyoiklim sınıflandırması çalışmasını Pasifik ve Meksika için gerçekleştirmiştir.

Türkiye'de coğrafi konum, denizellik-karasallık ve topografik değişkenlik gibi özellikleri iklimin bölgesel olarak farklılaşmasına ve tüm bu faktörlerin ortak etkisi sonucunda doğal bitki örtüsünde önemli bir çeşitliliğin ortaya çıktı̆̆ ifade edilebilir. Günal (2013)'a göre bu farklılaşmalar Türkiye'nin relik ve endemik bitkiler bakımından da son derece zengin olmasını sağlamıştır. Türkiye'de Avrupa-Sibirya flora bölgesi, Akdeniz flora bölgesi ve İran-Turan flora bölgesi olmak üzere üç flora bölgesi temsil edilir (Avcl, 1993). Avrupa- Sibirya flora bölgesi Öksin ve Hırkaniyen olarak ikiye ayrılmış, Karadeniz'e yakın olan batıdaki saha Öksin, İran'ın kuzeyi ve Taliş dağlarının bulunduğu alan Hırkaniyen olarak isimlendirilmiştir (Avcl, 2005). Akdeniz flora bölgesi de üçe ayrılmıştır: Bat Anadolu, Bat-Orta Toroslar ve Amanoslar. Bat Anadolu, Akdeniz kıyılarındakilere benzer bitki topluluklarının olduğu sahayı kapsamaktayken; Bat ve Orta Toroslar Alp orojenik kuşağının güney kolunu temsil eder ve endemiklerin yoğun olduğu önemli bir ekosistem alanıdır (Şenkul \& Kaya, 2017; Avcı, 2005). Amanos Dağları ise; yaz aylarında düşen yağış miktarı ve nemin fazlalığıyla flora tarihi açısından önemli bir sahayı oluşturmaktadır. Bu saha Pleistosen'de göç rotası olarak belirlenmiştir (Avcı, 1993; Çakan \& Byfield, 2005). İran-Turan flora bölgesi ise İç Anadolu, Doğu Anadolu ve Güneydoğu Anadolu bölgelerini içine alır. Bu saha step, dağ stepi ve yarı kurak özellik göstermektedir. Türkiye'de kendisini çevreleyen Avrupa-Sibirya ve Akdeniz flora bölgelerinin özelliklerini taşır (Avcl, 2005).

Türkiye için bugüne kadar, bazıları biyoiklim ile doğrudan ilişkili olmak üzere çeşitli iklim sınıflandırması çalışmaları yapılmıştır. Aydeniz iklim sınıflandırmasında yağış, sıcaklık, nispi nem ve güneşlenme süresi verileri kullanılmaktadır (Aydeniz,
1988). Aydeniz özellikle kurak dönemlerin ve indislerin belirlenmesinde, sadece yağış ve sıcaklık parametrelerinin kullanımının yetersiz olduğunu ve gerçeğe yakın değerlerin elde edilmesinde nem-yağış ilişkisi ile sıcaklık-güneşlenme müddeti ilişkilerinin göz önünde bulundurulmasının daha uygun sonuçlar vereceğini düşünerek bu alanda bir formül geliştirmiştir (Bölük, 2016). Erinç yöntemi olarak bilinen iklim sınıflandırmasında, yağış ve buharlaşmanın neden olduğu su kaybına yol açan yıllık ortalama maksimum sıcaklık verisini kullanmıştır (Erinç, 1984). Bu yöntemde, evapotranspirasyon ile su kaybının neden olduğu kuraklık ve yağış ilişkisi dikkate alınarak gerçekleştirdiği hesaplamalara göre, yağış etkinlik indeksini belirlemiştir. Tugay ve Akdağ (1989), Walter (1970) yöntemini kullanarak Türkiye'de iklim ve tarım bölgelerini sınıflandırmış ve Türkiye 15 iklim bölgesine ayrılmıştır. Türkiye'de kümeleme çalışmalarına öncü iklim sınıflandırması çalışması Ünal vd. (2003) tarafindan gerçekleştirilmiştir. Kümeleme analizi altında yer alan farklı yöntemleri karşılaştırdıkları çalışmada, Türkiye'nin iklim bölgelerini 7 küme halinde en iyi şekilde Ward's yönteminin açıkladığını tespit etmişlerdir. Türkiye'deki büyük ekosistemlerin dağıımı için ayırt edici biyoiklim kontrollerin belirlenmesi amacını taşıyan bir diğer çalışmada; 272 meteoroloji istasyonunda 1968-2004 dönemi için toplam $12 \mathrm{iklim}$ değişkeni ve 11 biyoiklim indisi ve dört konum verisi (enlem, boylam, yükseklik ve mesafe) ile hiyerarşik ve hiyerarşik olmayan kümeleme analizi (Cluster Analysis,CA), asal bileşen analizi (Principal Component Analysis, PCA) ve çoklu doğrusal regresyon (Multiple Linear Regression,MLR) modelleri uygulanmıştir (Evrendilek \& Berberoğlu, 2008). Kümeleme analizi sonucunda \%97'lik bir iklimsel benzerlik temelinde gözlemlenebilen yedi küme (iklim türü) saptanmış; ayrıca PCA analizine göre 1 . faktör veri kümesindeki varyasyonun \%78'ini açıkladığı belirlenmiştir. (Evrendilek \& Berberoğlu, 2008). Son yıllarda gelişmiş alansal istatistik yöntemlerle Thornthwaite ve Köppen-Geiger iklim sınıflandırmalarının Türkiye için yeniden değerlendirildiği bazı çalışmalardan da bahsetmek gerekir. Yılmaz ve Çiçek (2016) Türkiye'nin 805.000 noktasında aylık ortalama yağış ve sıcaklık verilerini düzenleyerek Thornthwaite iklim sınıflandırma yöntemine göre analiz ettikleri çalışmada dört farklı kategoride sonuçlara ulaştılar. Bu çalışmada elde edilen bulgulara göre, Türkiye'de 8 farklı yağış etkinlik indisi, 8 farklı sıcaklık tesiri indisi, 6 farklı kuraklık ve nemlilik indisi ve 8 farklı potansiyel buharlaşma indis sınıfinın olduğu belirlenmiştir. Öztürk vd. (2017) Türkiye için 512 istasyonun aylık sıcaklık ve yağış verilerini kullanarak gerçekleştirdikleri Köppen-Geiger iklim sınıflandırmasında; 3 ana iklim tipi içerisinde 10 alt iklim tipi belirlemişlerdir. Çalışmada en geniş yayılıma kışları ılıman orta enlem iklimi (C) ve bu iklim tipleri içerisinde ise tipik Akdeniz iklimine karşılık gelen Csa ikim tipi olduğu belirtilmiştir. Son olarak, Yılmaz ve Çiçek (2018) Köppen-Geiger yönteminin, Türkiye'ye yeniden uyguladıkları, ulusal ve küresel iki farklı veri setiyle gerçekleştirdikleri çalışmada Türkiye için 13 iklim bölgesi tespit etmişlerdir.

İklim değişikliği ve antropojenik başka etkilere bağlı olarak değişen ortamsal özellikler, bitkilerin yaşam şartları üzerinde etkilidir. Bitkilerin yetişme şartlarının ne yönde ve şiddette değiştiğini belirleyebilmek için öncelikli olarak bölgede var olan biyoiklim karakteristiğini tanımlamak ve bitki çeşitliliği/ dağılışı ile olan ilişkisini açıklamak gerekmektedir. Türkiye için daha önce gerçekleştirilen ve yukarıda özetlenen iklimsel sınıflandırmalara ek olarak bu çalışmada, 19 biyoiklim değiş- 


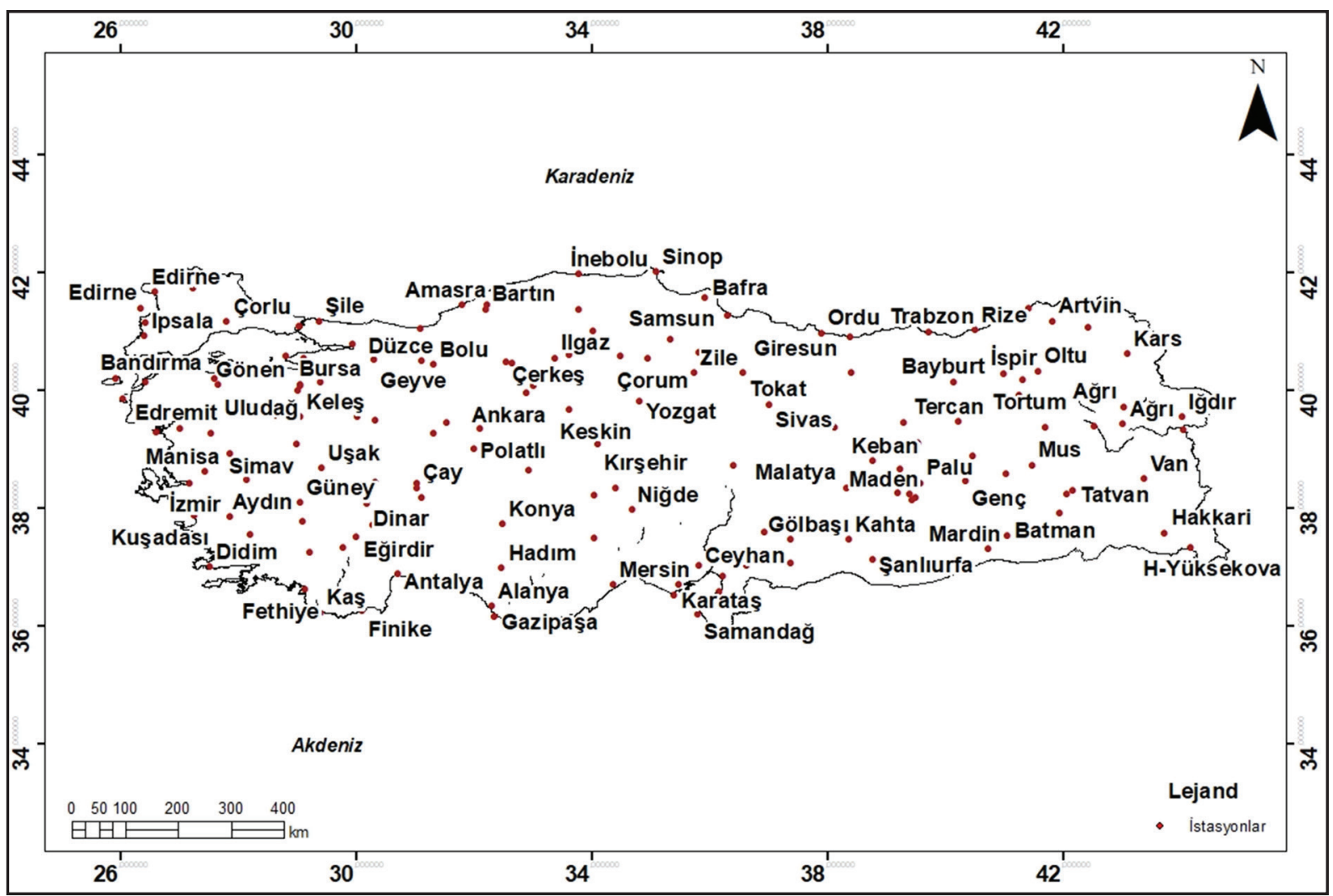

Şekil 1. Biyoiklim indisleri sınıflandırması için seçilen meteoroloji istasyonları. Figure 1. Meteorological Stations selected for bioclimatic indices classification.

kenini uzun süreli ve güncel veri ile 3 farklı veri seti (sıcaklık, yağış, tümü) ile analiz etmek hedeflendi. Ayrıca biyoiklimsel bölgelerin klimatolojik karakterini tanımlamak ve öne çıkan özelliklerini saptamak ve böylelikle bölgesel farklılaşmada rol oynayan iklimsel nedensellikleri vurgulamak da çalışma kapsamında yer alır.

Bu çalışmanın amacı, Türkiye için 19 biyoiklim değişkenine dayanarak kümeleme analizi ile biyoiklim sınıflandırması yapmak ve saptanan biyoiklim bölgelerini öne çıkan özelliklerine göre tanımlamaktır. Ortaya çıkan biyoiklim bölgelerinin iklimsel farklılıkları ve bitki örtüsü dağılışı açısından değerlendirilmesine de hakim orman formasyonları özelinde yer verildi.

\section{Veri ve Yöntem}

Biyoiklim indislerinin hesaplanması için Devlet Meteoroloji İşleri Genel Müdürlüğü'ne ait toplam 169 istasyonda (Şekil 1) 1960-2016 yılları arasında 57 yıl boyunca kesintisiz kaydedilen aylık ortalama sıcaklık, maksimum sıcaklık, minimum sıcaklık ve toplam yağış verileri değerlendirildi. Değişkenlik desenlerini kapsamlı bir şekilde ele alabilmek için, olabilecek en yüksek zamansal ve alansal çözünürlük değerlendirilmeye çalışıldı.

Tablo 1. Sınıflandırması için değerlendirilen biyoiklim değişkenleri (USGS, 2012).

Table 1. Bioclimatic variables evaluated for classification (USGS, 2012).

\begin{tabular}{|l|l|}
\hline BIO1 & Yılık Ortalama Sıcaklık \\
\hline BIO2 & Ortalama günlük aralık (Aylık ortalama (mak sıcaklık- min sıcaklık)) \\
\hline BIO3 & İzotermalite (BıO2 / BIO7) (* 100) \\
\hline BIO4 & Sıcaklık mevsimselliği (standart sapma * 100) \\
\hline BIO5 & En Sıcak Ayın Maksimum Sıcaklığı \\
\hline BIO6 & En Soğuk Ayın Minimum Sıcaklığı \\
\hline
\end{tabular}

\begin{tabular}{|l|l|}
\hline BI07 & Yılık Sıcaklık Aralığı (BıO5-BıO6) \\
\hline BI08 & En Yağışlı Çeyreğin Ortalama Sıcaklığı \\
\hline BI09 & En Kurak Çeyreğin Ortalama Sıcaklı̆̆ı \\
\hline BI010 & En Sıcak Çeyreğin Sıcaklık Ortalaması \\
\hline BI011 & En Soğuk Çeyreğin Sıcaklık Ortalaması \\
\hline BI012 & Yıllık Yağış \\
\hline BI013 & En Yağışlı Ayın Yağış Değeri \\
\hline BI014 & En Kurak Ayın Yağış Değeri \\
\hline BI015 & Yağış mevsimselliği (Değişkenlik Katsayısı) \\
\hline BI016 & En Nemli Çeyrekteki Yağış \\
\hline BI017 & En Kurak Çeyrekteki Yağış \\
\hline BI018 & En Sıcak Çeyrekteki Yağış \\
\hline BI019 & En Soğuk Çeyrekteki Yağış \\
\hline
\end{tabular}

\subsection{Biyoiklim Değişkenlerinin Hesaplanması}

Amerika Birleşik Devletleri Jeoloji Araştırmaları (USA Geological Survey), tür fizyolojisi ile en iyi ilişkili iklim koşullarını vurgulayan, biyoiklim değişkenler olarak adlandırılan iklim indislerini geliştirmiştir (USGS, 2012). Biyoiklim değişkenler, daha fazla biyolojik olarak anlamlı değişkenler üretmek için aylık sıcaklık ve yağış değerlerinden türetilmiştir. Bunlar genellikle tür dağılımı modelleme ve ilgili ekolojik modelleme tekniklerinde kullanılır. Biyoiklimsel değişkenler, yıllık eğilimleri (yılık ortalama sıcaklık, yıllık yağış), mevsimsellik (sıcaklık ve yağış alanındaki yıllık aralığı) ve aşırı veya sınırlayıcı çevresel faktörleri (en soğuk ve en sıcak ayın sıcaklığı, yağışı ve kurak çeyrekler) kapsamaktadır. Tablo 1'de biyoiklim sınıflandırması için kullanılan 19 değişken listelendi. 


\subsection{Kümeleme Analizi}

Kümeleme Analizi, (CA) X veri matrisinde yer alan ve doğal gruplamaları kesin olarak bilinmeyen değişkenleri birbiri ile benzer olan alt kümelere (grup, sınıf) ayırmaya yardımcı olan yöntemler topluluğudur. Kümeleme analizi; değişkenleri, birbirileri arasındaki benzerlik ya da farklılıklara dayalı olarak hesaplanan bazı ölçülerden yararlanarak homojen gruplara bölmek amacıyla kullanılır. Kümeleme analizi, nesneleri küme içerisinde çok benzer biçimde, kümeler arasında farklı olacak biçimde kümeler (Hair vd., 1995). Bu çalışmada, hiyerarşik kümeleme yöntemlerinden biri olan Ward's yöntemi kullanıldı. "En küçük varyans" yöntemi olarak da adlandırılan Ward's yöntemi kümeler içi varyansı en küçük yapmayı amaçlar. Hiyerarşik kümeleme yöntemleri, veri setinin birimlerinin birbirilerine olan uzaklık değerlerini kullanarak, veri setindeki birimlerin hiyerarşik ayrıştırmasını yapar. Hiyerarşik ayrıştırma sırasında, "ağaç veri yapısı" olarak da bilinen dendogram kullanıır (Griffith \& Amrhein, 1997). Aynı zamanda anlamlı küme sayısını belirlemek için yığılma grafiği (agglomeration plot) de göz önünde bulunduruldu. Bu çalışmada; 169 meteoroloji istasyonu için hesaplanmış biyoiklimsel değişkenler üç grup halinde değerlendirildi: sıcaklık $\left(\mathrm{Bio}_{1}-\mathrm{Bio}_{11}\right)$, yağış $\left(\mathrm{Bio}_{12}-\mathrm{Bio}_{19}\right)$ ve genel grup $\left(\mathrm{Bio}_{1}-\mathrm{Bio}_{19}\right)$. Her bir grup için kümeleme analizi gerçekleştirildi. Kümeleme haritaları Türkiye yükselti modeli haritası üzerine aktarılarak, değerlendirmede yükselti faktörü de göz önünde bulundurulmuştur.

\section{Bulgular}

Kümeleme Analizi sıcaklığın baskın olduğu (BIO1 - BIO11) ve yağışın baskın olduğu (BIO12 - BIO19) değişkenler için önce ayrı ayrı uygulandı. Daha sonra, tüm değişkenlerin bir arada değerlendirildiği kümeleme analizine geçildi. Son olarak, tanımlanan 6 biyoiklim bölgesindeki baskın orman formasyonları değerlendirildi.

3.1. Sıcaklıkla İlişkili Biyoiklim Değişkenlerinin (BIO1 - BIO11) Analizi

169 istasyon için hesaplanan $\mathrm{BIO}$ - $\mathrm{BIO} 11$ parametrelerinin kümeleme analizi sonuçları, hem dendogram hem de yığılma grafiği dikkate alınarak değerlendirildi ve Türkiye için anlamlı 4 küme elde edildi. 169 istasyondan 34'ü 1. kümeyi, 25'i 2. kümeyi, $29^{\prime}$ u 3 . kümeyi, $81^{\prime}$ i ise 4 . kümeyi oluşturdu ve dağılışları Şekil 2'de gösterildi. Tablo 2'de ise biyoiklim değişkenlerinin kümelere göre ortalama değerleri verildi.

Tablo 2. BIO1-BIO11 değişkenlerinin kümelere göre ortalama değerleri.

Table 2. Average values of BIO1-BIO11 variables by clusters.

\begin{tabular}{|l|l|l|l|l|l|l|l|l|l|l|l|}
\hline & BIO1 & BIO2 & BIO3 & BIO4 & BIO5 & BIO6 & BIO7 & BIO8 & BIO9 & BIO10 & BIO11 \\
\hline Küme1 & 17.04 & 17.31 & 36.82 & 2.25 & 41.00 & -6.11 & 47.11 & 13.06 & 23.08 & 25.23 & 9.29 \\
\hline Küme2 & 15.89 & 25.86 & 44.29 & 3.18 & 44.02 & -14.82 & 58.85 & 8.65 & 25.85 & 27.34 & 4.81 \\
\hline Küme3 & 9.67 & 27.68 & 39.33 & 3.6 & 40.10 & -30.60 & 70.70 & 4.52 & 20.12 & 21.88 & -3.04 \\
\hline Küme4 & 11.81 & 20.95 & 34.04 & 2.76 & 41.05 & -20.73 & 61.78 & 7.76 & 19.75 & 21.51 & 2.23 \\
\hline
\end{tabular}

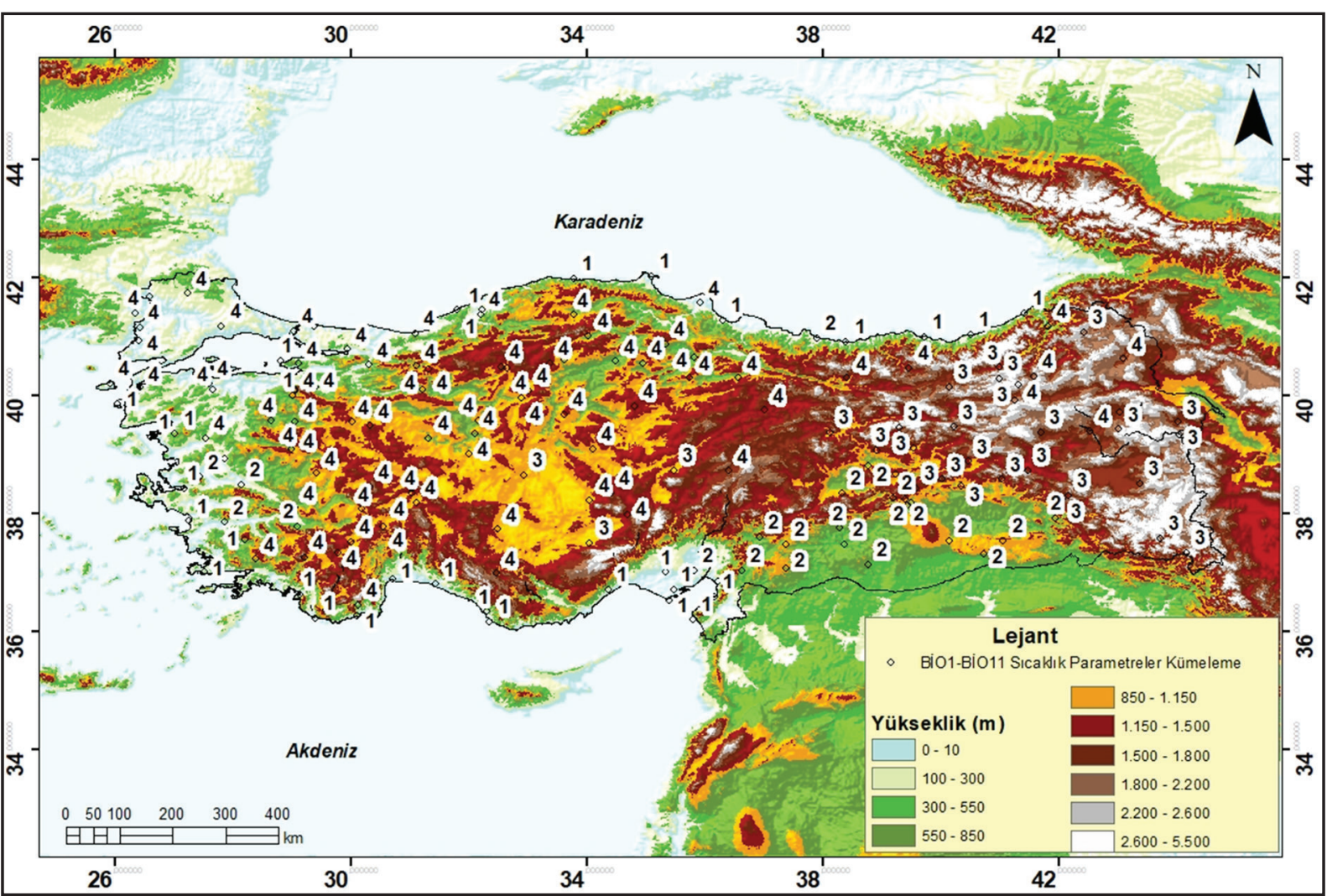

Şekil 2. BIO1-BIO11 indis değerlerinin kümeleme analizi sonuçları.

Figure 2. Cluster analysis results of BIO1-BIO11 index values. 
1. Kümeye giren istasyonlar $\mathrm{BIO} 2, \mathrm{BIO} 4$ ve $\mathrm{BIO}$ değişkenlerinin en düşük; $\mathrm{BIO} 1, \mathrm{BIO6}, \mathrm{BIO}$ ve $\mathrm{BIO} 11$ değişkenlerinin en yüksek değerlerine sahip istasyonlar yer alır. Bu istasyonların sıcaklık yönünden biyoiklim karakteristiği, sıcaklık farklarının (günlük, aylık ve yılık) önemsiz olması, ortalama günlük sıcaklık aralığının düşük olması, sıcaklık rejimi açısından mevsimselliğin belirgin olmaması şeklinde ifade edilebilir. Buna karşın yıllık ortalama sıcaklık değerleri yüksektir. Ayrıca en soğuk ayın minimum sıcaklığı ile en soğuk çeyreğin sıcaklık ortalamasının en yüksek olduğu istasyonlar bu kümede bir araya gelmiştir. Bu kümenin alansal dağılışın bakıldığında Akdeniz, Ege ve ile Karadeniz kıyısı boyunca devam ettiği gözlenebilir. Denizellik etkisinin öne çıktığı açıkça görülebilir. Biyoiklimsel olarak "sıcaklık farklarının en düşük olduğu, kış sıcaklıklarının yüksek olduğu bir bölge" olarak değerlendirilebilir.

2. küme, $\mathrm{BIO}$, BIO5, $\mathrm{BIO9}$ ve $\mathrm{BIO} 10$ değişkenlerinin en yüksek değerlerinin gözlendiği bir kümedir. Bu küme içerisinde herhangi bir indisinin minimum değeri belirlenmedi. En yüksek indis değerlerinin tespit edildiği parametrelere bakıldığında yüksek sıcaklarla karakterize bir küme olduğu ifade edilebilir. Burada izotermalite, en sıcak ayın maksimum sıcaklığı, en kurak çeyreğin ortalama sıcaklığı, en sıcak çeyreğin sıcaklık ortalaması gibi parametreler açısından Türkiye'deki en yüksek değerler bu küme içerisindeki istasyonlarda belirlendi. 2 . kümenin alansal olarak Güneydoğu Anadolu Bölgesi'nin geniş düzlük ve ovalarında aynı zamanda İç Batı Anadolu bölümünde dağılış gösterir. Güneydoğu Anadolu Bölgesi zaten Türkiye'de en yüksek sıcaklıkların gözlendiği bir bölgedir. Karasallık etkisinin bu grupta ön plana çıktığı ifade edilebilir. Ancak yükseltisi çok yüksek olmayan alanlarda bir yayılış söz konudur. Biyoiklimsel olarak "en yüksek sıcaklıkların olduğu" bölge olarak nitelendirilebilir.

3. kümeyi kapsayan istasyonlar $\mathrm{BIO1}, \mathrm{BIO}$, $\mathrm{BIO} 6$ ve $\mathrm{BIO} 8$ değişkenlerinin en düşük değerleri; $\mathrm{BIO} 2, \mathrm{BIO} 4$ ve $\mathrm{BIO}$ değişkenlerinin ise en yüksek değerleri ile öne çıkan istasyonlardır. Bu kümenin sıcaklık karakteri, 1. kümenin tam tersine minimum sıcaklıklarla ifade edilebilir. Yıllık ortalama sıcaklık, en sıcak ayın maksimum sıcaklığı, en soğuk ayın minimum sıcaklığı ve en yağışlı çeyreğin ortalama sıcaklığı bu istasyonlarda en düşük değerdedir. Yine aynı şekilde 1. kümenin tam tersi şekilde, sıcaklık farkları (günlük, aylık ve yıllık) bu kümede çok yüksektir. Ortalama günlük sıcaklık aralığının en yüksek olduğu ve sıcaklık rejimi açısından mevsimselliğin belirgin bir şekilde öne çıktı̆ı bir kümedir. 3. kümenin alansal dağılışı ağılıklı daha

Tablo 3. BIO12-BIO19 değişkenlerinin kümelere göre ortalama değerleri.

Table 3. Average values of BIO12-BIO19 variables by clusters.

\begin{tabular}{|l|l|l|l|l|l|l|l|l|}
\hline & BIO12 & BIO13 & BIO14 & BIO15 & BIO16 & BIO17 & BIO18 & BIO19 \\
\hline Küme1 & 714.6 & 128.9 & 3.2 & 72.3 & 115.5 & 6.2 & 7.4 & 109.4 \\
\hline Küme2 & 453.0 & 60.8 & 9.2 & 46.8 & 58.2 & 12.8 & 16.8 & 49.0 \\
\hline Küme3 & 1077.9 & 244.9 & 2.7 & 90.5 & 209.9 & 5.5 & 5.7 & 190.7 \\
\hline Küme4 & 829.1 & 106.5 & 33.9 & 35 & 101.1 & 40.7 & 48.3 & 77.0 \\
\hline Küme5 & 2184.7 & 296.4 & 40.5 & 38.2 & 266.4 & 92.5 & 159.0 & 176.1 \\
\hline
\end{tabular}

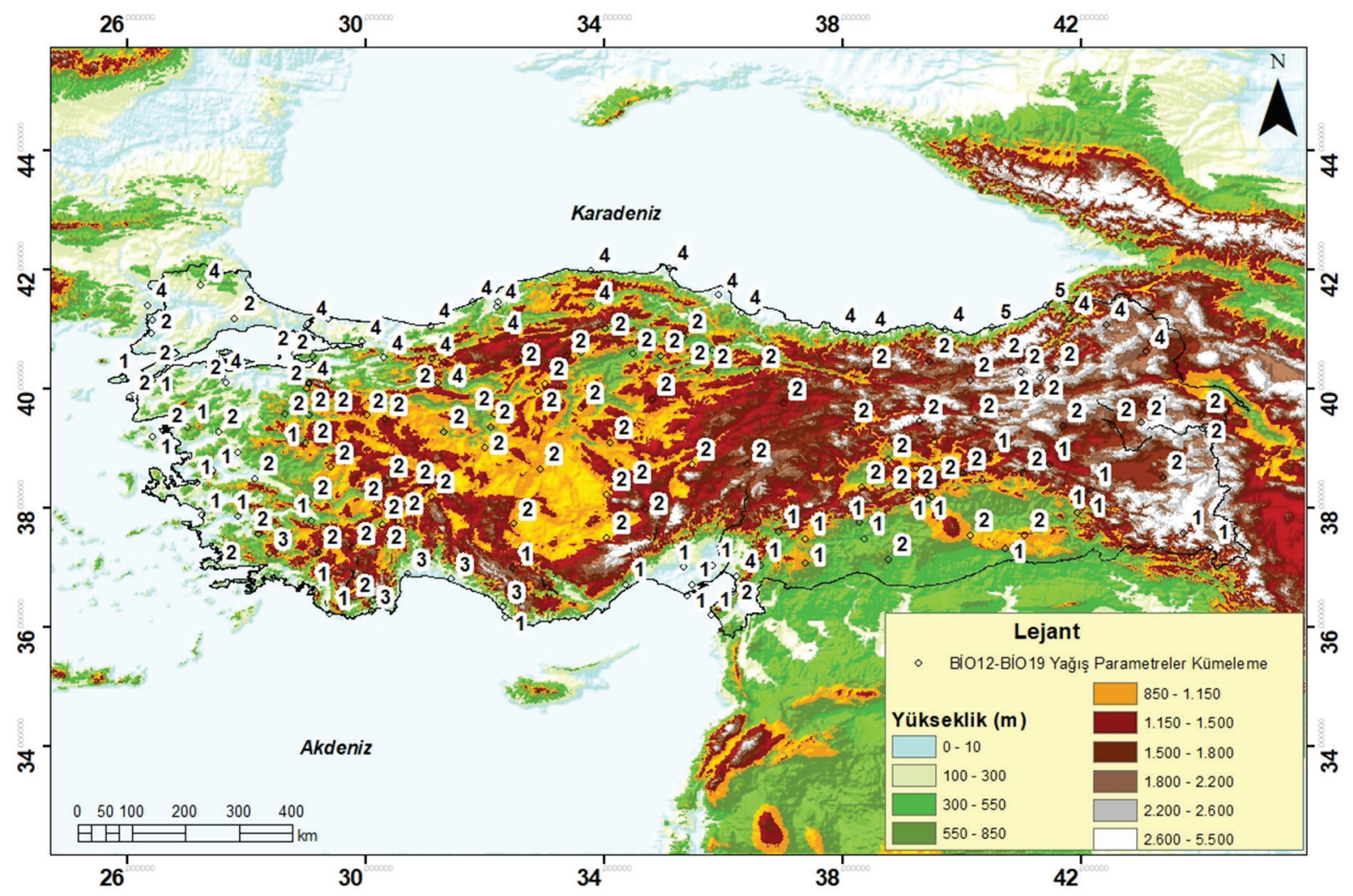

Şekil 3. BIO12-BIO19 indis değerlerinin kümeleme analizi sonuçları.

Figure 3. Cluster analysis results of BIO12-BIO19 index values. 
çok plato alanlara karşılık gelir. Topografik olarak Türkiye'nin en yüksek bölgesine karşılık gelen bu alanın sıcaklık rejimine paralel olarak biyoiklimsel sıcaklık karakteri de "en soğuk ve sıcaklık farklarının en yüksek olduğu" bölge olarak ifade edilebilir.

4. Küme izoterm değeri toplamda 81 istasyon ile en geniş alana yayılır. Yer yer Doğu Anadolu'da da gözlense de alansal olarak tutarlı dağılımlar, i̇ç Anadolu Bölgesi (batı ve doğu yönlere doğru genişleyerek ve Trakya bölümünde belirgindir. Daha çok plato alanlarında dağılış söz konusudur. Biyoiklim karakterine gelince, $\mathrm{BIO}$, $\mathrm{BIO9}$ ve $\mathrm{BIO} 10$ değişkenlerinin en düşük değerleri bu kümede gözlenir. En yüksek olduğu hiçbir değişken yok. Bu küme içerisinde herhangi bir indisinin maksimum değeri belirlenmedi. En düşük olduğu biyoiklim parametreleri İzoterm değeri, en kurak çeyreğin ortalama sıcaklığı, en sıcak çeyreğin sıcaklık ortalamasıdır. Bu kümedeki değişken değerleri 2. küme ile kontrast göstermektedir. Sıcak dönemde minimum değerlerin öne çıktı̆ı bir bölgedir. Aslında biyoiklim karakteri olarak 2. ve 3. kümeye oldukça benzer bir kümedir. Özellikle sıcak ve kurak dönemlerdeki minimum değerler açısından 3.kümeyle arasında değerler bazında çok az sayısal farkların olması, bu kümenin karakterize edilmesin güçleştirir.

\subsection{Yağışla illişkili Biyoiklim Değişkenlerinin (BIO12-BIO19) Analizi}

169 istasyon için hesaplanan $\mathrm{BIO} 1$ - BIO11 parametrelerinin kümeleme analizi sonuçları, hem dendogram hem de yığılma grafiği dikkate alınarak değerlendirildi ve Türkiye için anlamlı 5 küme elde edildi. Burada 169 istasyon yağış özelliklerine göre 1. kümede 42 istasyon, 2 . kümede 93,3 . kümede 5,4 . kümede 27,5 . kümede 2 istasyonu kapsayan kümeler oluşmuştur (Şekil 3).

1. kümede hiçbir değişkende en yüksek veya en düşük değer belirlenmemesine rağmen, indis değerleri diğer gruplara oranla çok düşüktür. 1. kümenin dağılış gösterdiği bölgede yaz kuraklığı şiddetli yaşanmakta, kış yağışları etkili olmaktadır. Bu alan diğer kümelere oranla daha kurak bölgeyi oluşturmaktadır. Birinci Kümeyi oluşturan 42 istasyon Doğu Anadolu Bölgesi'nde Hakkari istasyonundan başlayıp Akdeniz kıyısı boyunca devam ederek Ege Bölgesi'nin Güney Marmara Bölgesi ile kesiştiği yere kadar sahil boyunca dağılış göstermektedir.

2. küme İstasyon sayısı en yüksek kümedir. Bu kümede BIO12, BIO13, BIO16 ve BIO19 parametrelerinin en düşük değerleri vardır (Tablo 3). Maksimum değerlerin gözlendiği her hangi bir değişken bulunmaz. Bu duruma göre, 2. küme içerisindeki istasyonlar yıllık yağış, en yağışlı aydaki yağış, en nemli çeyrekteki yağış ve en soğuk çeyrekteki yağış toplamlarının en düşük olduğu noktalardır. Dolayısıyla bu küme için yağışın düşük olduğu bir küme denilebilir. Türkiye'nin en doğusundan en batsına kadar geniş bir alanda yayılış göstermiştir.

3. kümeyi 5 istasyon oluşturmaktadır. Kümeye giren istasyonlar Finike, Antalya, Manavgat, Alanya ve Muğla istasyonlarıdır. Bu kümede $\mathrm{BIO} 14, \mathrm{BIO} 17$ ve $\mathrm{BIO} 18$ değişkenleri en düşük indis değerlerine sahipken; $\mathrm{BIO} 15$ ve $\mathrm{BIO} 19$ en yüksek indis değerlerine sahiptir. Bu istasyonlarda en kurak ayın yağış değeri en sıcak ve en kurak çeyrekteki yağış değerleri tüm istasyonlar içinde minimumdur. Belirgin bir yaz kuraklığını görüldüğü aynı zamanda yağışın mevsimselliğinin de oldukça yüksek olduğu bir küme olarak tanımlanabilir; nitekim BIO15 yağışın mevsimselliğini gösteren bir indistir ve bu oran bu küme de \%90'ın üzerindedir (Tablo 3). Dikkat çeken bir diğer özelliği de en soğuk çeyrekteki yağışın en yüksek olmasıdır. Bu nitelik de, kış dönemindeki yağış mevsimselliğinin ve yüksek yağışın tutarlarının bir sonucudur.

4. küme Karadeniz kıyı kuşağını, Marmara Bölgesi'nde Gönen istasyonunu ve Doğu Anadolu'da Ardahan ve Kars istasyonlarını kapsamaktadır. Bu kümenin en önemli özelliği yağış mevsimselliğinin en düşük olduğu küme olmasıdır.

5. Küme'de Rize ve Hopa istasyonları bulunmaktadır. BIO15 ve BIO19 hariç tüm değişkenlerin en yüksek değerlerine bu iki istasyon sahiptir. Rize ve Hopa'da yıllık yağış, en yağışlı ayın yağış değeri, en kurak ayın yağış değeri, en nemli çeyrekteki yağış, en kurak çeyrekteki yağış ve en sıcak çeyrekteki yağış değerleri en yüksektir. Bu iki istasyon zaten Türkiye'nin en fazla yağış alan iki istasyonu olarak bilinmektedir (Sariş vd., 2010).

\subsection{BIO1-BIO19 İçin Yapılan Kümeleme Analizi}

Şekil 4 BIO1-19 değişkenleri için yapılan kümeleme analizinin sonuçlarını göstermektedir. Bu analize göre 6 küme ayırt edildi. Tablo 4 belirlenen kümeler içerisindeki istasyonların indis değerleri ortalamalarını gösterir. Analiz sonucunda ortaya çıkan 6 kümenin dağılışı şu şekilde özetlenebilir: 1. Küme 28 istasyonla Ege-Akdeniz bölgesi kıyı kesimlerini; 2. Küme 35 istasyon ile Güneydoğu Anadolu Bölgesi ve Doğu Toroslar'ı ; 3. Küme 9 istasyon Doğu Anadolu Bölgesi'nde dağınık bir örüntüyü; 4. Küme 53 istasyonla İç /Doğu Anadolu Bölgelerini; 5 Küme 29 istasyon ile kabaca Marmara Bölgesi'ni ve son olarak 6. Küme ise 15 istasyonla Karadeniz Kıyı Bölgesi'ni kapsamaktadır.

Küme 1: $\mathrm{BIO}$, BIO5, $\mathrm{BIO6}, \mathrm{BIO}$, $\mathrm{BIO9,} \mathrm{BIO10,} \mathrm{BIO} 11$ ve $\mathrm{BIO} 19$ parametrelerinin en yüksek değere sahip istasyonları, BIO7'nin ise en düşük değere sahip istasyonları. Daha çok sıcaklık karakteriyle öne çıkan bir biyoiklim bölgesidir. Tüm kümeler içerisindeki en sıcak ve yıllık sıcaklık aralığının düşük olduğu bir kümedir. Türkiye'nin Ege ve Akdeniz kıyıları boyunca yayılış gösterir.

Küme 2: BIO3 (izotermalite) değişkeninin en yüksek, BIO14, BIO17 ve BIO18 yağış değişkenleri bakımından en düşük değere sahip istasyonların yer aldığı kümedir. Kurak ay/mevsimlerdeki düşük yağış karakteriyle dolayısıyla "kurak" özelliği ile dikkati çeker. Bat Anadolu'daki bir-iki istasyon dışında, tamamen Güneydoğu Anadolu Bölgesinde yayılış gösterir.

Küme 3: Küme 1'in tam karşıt kümesidir. Çok kısıtlı bir yayılış alanı vardır. En düşük sıcaklık değerleri dolayısıyla, en soğuk biyoiklim bölgesi olarak karakterize edilebilir. İstasyon sayısının da en düşük olduğu kümedir ve doğu - kuzey doğu aralığında dağınık sayılabilecek bir örüntüsü vardır.

Küme 4: Bu kümede $\mathrm{BIO} 12, \mathrm{BIO} 13$ ve $\mathrm{BIO} 16$ yağış değişkenlerinin en düşük değerde olduğu istasyonlar yer alır. Bu değişkenlerdeki düşük değerler yağışlı dönemdeki yağış azlığına işaret eder. Dolayısıyla yine kurak olma özelliği ile dikkat çeken bir kümedir ve yayılış alanı oldukça geniştir. İç Anadolu bölgesinin neredeyse tamamı ve kısmen Doğu Anadolu Bölgesinde dağılış gösteren bir kümedir. Küme 2 ile yağış açısından yakın 
Tablo 4. BIO1-BIO19 değişkenlerinin kümelere göre ortalama değerleri.

Table 4. Average values of BIO1-BIO19 variables by clusters.

\begin{tabular}{|l|l|l|l|l|l|l|}
\hline & Küme 1 & Küme 2 & Küme 3 & Küme 4 & Küme 5 & Küme 6 \\
\hline $\mathbf{B I O}_{1}$ & 18.1 & 13.5 & 6.5 & 10.9 & 13.7 & 13.3 \\
\hline $\mathbf{B I O}_{2}$ & 18.5 & 27.0 & 28.0 & 22.6 & 19.4 & 17.6 \\
\hline $\mathbf{B I O}_{3}$ & 37.5 & 42.9 & 37.6 & 34.7 & 34.1 & 35.9 \\
\hline $\mathbf{B I O}_{4}$ & 2.4 & 3.4 & 3.7 & 3.0 & 2.5 & 2.2 \\
\hline $\mathbf{B I O}_{\mathbf{5}}$ & 42.9 & 42.5 & 37.9 & 40.9 & 41.5 & 38.7 \\
\hline $\mathbf{B I O}_{\mathbf{6}}$ & -6.4 & -20.8 & -36.5 & -24.5 & -15.5 & -11.1 \\
\hline $\mathbf{B I O}_{\mathbf{7}}$ & 49.3 & 63.3 & 74.5 & 65.3 & 57.0 & 49.8 \\
\hline $\mathbf{B I O}_{\mathbf{8}}$ & 12.0 & 6.3 & 3.5 & 8.3 & 7.7 & 11.2 \\
\hline $\mathbf{B I O}_{9}$ & 25.9 & 24.4 & 11.8 & 19.6 & 21.3 & 18.3 \\
\hline $\mathbf{B I O}_{10}$ & 26.8 & 25.7 & 18.4 & 21.2 & 22.8 & 21.2 \\
\hline $\mathbf{B I O}_{11}$ & 9.8 & 1.5 & -6.8 & 0.5 & 5.0 & 6.0 \\
\hline $\mathbf{B I O}_{12}$ & 745.8 & 642.7 & 483.1 & 399.8 & 617.0 & 1165.5 \\
\hline $\mathbf{B I O}_{13}$ & 149.2 & 102.5 & 53.8 & 49.4 & 90.4 & 151.1 \\
\hline $\mathbf{B I O}_{14}$ & 4.0 & 2.5 & 17.6 & 10.3 & 16.8 & 40.9 \\
\hline $\mathbf{B I O}_{15}$ & 75.6 & 67.9 & 43.2 & 41.5 & 43.8 & 34.6 \\
\hline $\mathbf{B I O}_{16}$ & 129.3 & 96.8 & 64.4 & 48.3 & 79.7 & 141.5 \\
\hline $\mathbf{B I O}_{17}$ & 7.3 & 5.0 & 19.2 & 13.4 & 22.3 & 56.9 \\
\hline $\mathbf{B I O}_{18}$ & 8.3 & 6.4 & 32.4 & 18.8 & 24.0 & 72.0 \\
\hline $\mathbf{B I O}_{19}$ & 119.0 & 90.7 & 33.9 & 39.4 & 72.2 & 102.4 \\
\hline & & & & & & \\
\hline
\end{tabular}

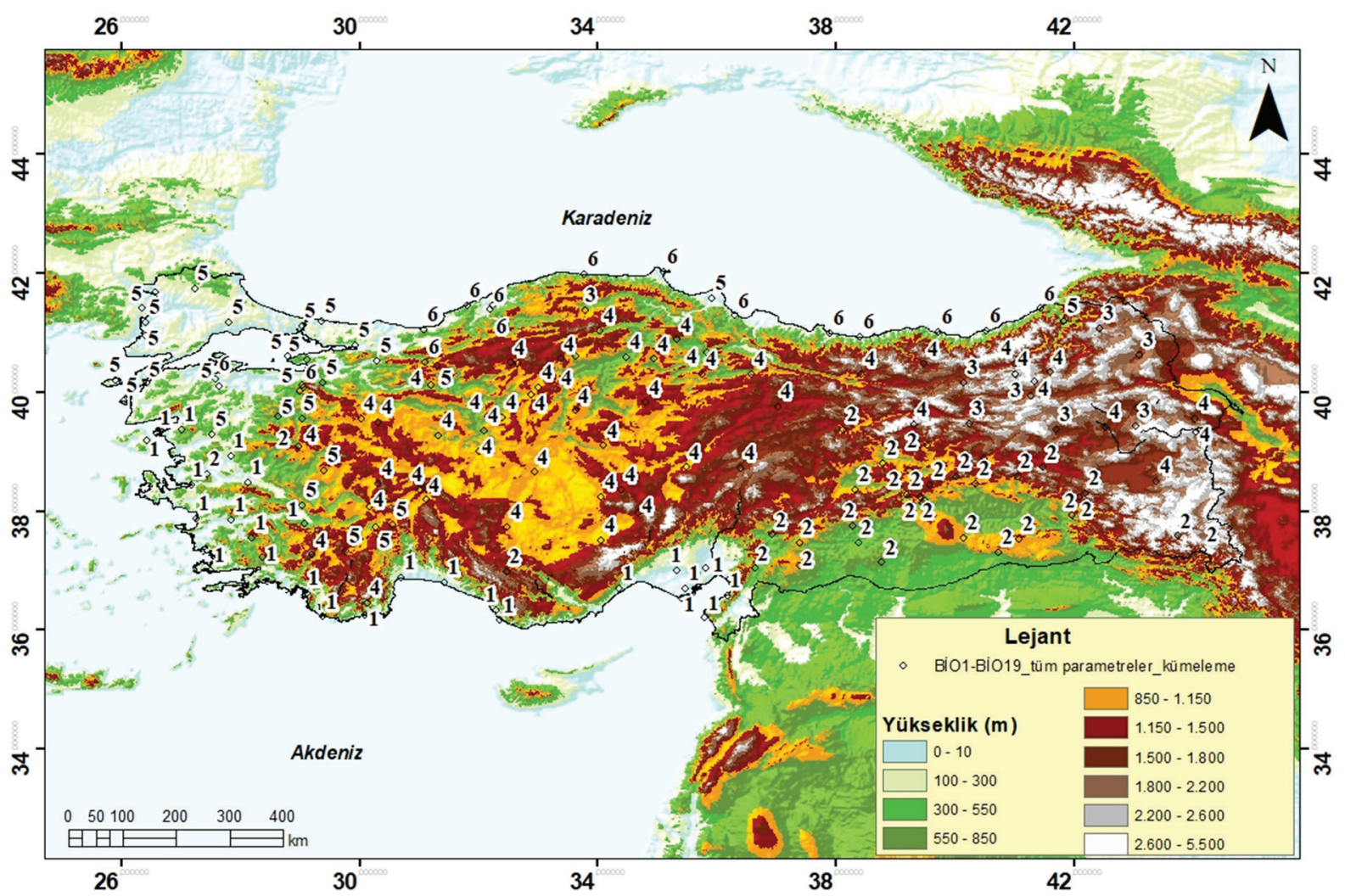

Şekil 4. BIO1-BIO19 indis değerlerinin kümeleme analizi sonuçları.

Figure 4. Cluster analysis results of BIO1-BIO19 index values.

karakterde sayılabilirse de sıcaklığın daha düşük olması ile kümeden farklılaşır.

Küme 5: Bu kümeyi, diğer kümelerden açıkça ayırt edebilecek bir biyoiklim karakterinden bahsedilemez. Sıcaklık özellikleri açısından Küme 4'e ve yağış özellikleri açısından da Küme 6'ya yakın bir niteliğe sahiptir. Marmara Bölgesi dahilinde tanımlanmış bir kümedir.

Küme 6: Küme 2 ve 4'ün karakter olarak karşıt kümesidir. Söz 
konusu kümelerde en düşük değerlerle tanımlanan BIO12, $\mathrm{BIO} 13, \mathrm{BIO} 14, \mathrm{BIO} 16, \mathrm{BIO} 17$ ve $\mathrm{BIO} 18$ bu küme içerisindeki istasyonlarda en yüksek değerlere sahiptir. Dolayısıyla yağışın ön planda olduğu ve "nemlilik" özelliği ile öne çıkan bir biyoiklim karakterinden söz edilebilir. Bu küme Türkiye'nin Karadeniz kıyısı boyunca yayılış gösterir.

Kümeleme analizi sonucunda elde edilen harita (bu bölümde karışıklık olmaması için "BIO1-19 Haritası” olarak kullanılacak), biyoiklim ile ilişkili diğer iklim sınıflandırma yöntemleri sonucunda elde edilen harita çıktıları ile karşılaştırıldı. Evrendilek ve Berberoğlu (2008) 4 farklı kümeleme yöntemi sonucunda, 7 biyoiklim bölgesi elde ettiler. Bölgelerin biyoklimatik özellikleri açıklanmamış olduğundan yalnızca alansal değişkenlik özelinde değerlendirildiğinde; Marmara bölgesi dışında elde edilen iç ve kıyı bölge ayrımlarının, BıO1-19 haritasındaki bölgesel paternle uyum gösterdiği ifade edilebilir. Yılmaz ve Çiçek (2016) tarafindan, Thornthwaite iklim sınıflandırması çevresinde oluşturulan 3 farklı haritayla (yağış etkinliği, sıcaklık tesiri, nemlilik/kuraklık) karşılaştırma yapıldı. Yağış etkinliği haritasındaki alansal desende, kurak-yarı nemli olarak gösterilen C1 sınıfindaki alanlar ile D sınıfinda yer alan yarı kurak alanlar İç Anadolu ve Güneydoğu Anadolu'da baskındır. Nemli iklimler Türkiye'nin kuzeydoğusunda ağılıklı olmak üzere doğuda ve lokal olarak da bat da tespit edilmiştir. Yağış etkinliği yönünden iç-kıyı bölge kontrastı ile, nemli kuzeydoğu paterni BıO119 haritasında da gözlenir ve bu açıdan iki harita paralellik gösterdiği belirtilebilir. Yılmaz ve Çiçek'in sıcaklık tesiri haritasında Türkiye'de orta ve düşük sıcaklık dağılışının hakim olduğu görülür. Sıcaklık tesirinin alansal dağılışı açısından da BIO119 haritası ile benzerlikler olmakla birlikte, Marmara bölgesi Bı01-19 haritasında, özellikle Trakya daha görece düşük sıcaklık karakteriyle öne çıkar. Yılmaz ve Çiçek'in Nemlilik/kuraklık indis dağılışını gösterdikleri haritada ise, su noksanı olmayan ya da çok az olan sahalar, Doğu Karadeniz Bölümü’nün kıyı ve dağlık kesiminde ve Karadeniz kıyı kuşağı boyunca dağlık alanlarda yer alır. Kurak olarak tanımlanan ve su fazlası olmayan ya da çok az olan sahalar, ağırlıklı olarak Güneydoğu Anadolu - İç Anadolu bölgeleri ile lokal olarak Doğu ve Bat bölgelerde belirlendi. Bu dağılış deseni BIO1-19 haritası ile oldukça benzer özelliklere işaret eder.

Elde edilen kümelere bakıldığında, enlem, denizellik-karasallık gibi faktörlerin yanı sıra Türkiye iklimini şekillendiren topografik faktörlerin (özellikle bakı ve yükseklik) biyoiklim sınıflandırmasında da etkili olduğu gözlenebilir. Birleşik kümeleme analizi sonucunda elde edilen dağılış (BIO1-19) ile temel orman formasyonlarının dağııışı arasındaki ilişki Orman Genel Müdürlüğü (2008) arazi örtüsü haritası ve Günal'dan (2013) yararlanılarak kurulmaya çalışıldı. Birinci kümenin yayılış gösterdiği alanda, Ege ve Akdeniz kıyı kuşağında yoğun olarak kızılçam, aynı zamanda ardıç ve meşe ormanları bulunmaktadır. Yüksek kesimlerde sıcaklığın düşmesi ve yağışın artmasına bağlı olarak orman örtüsü değişmeye başlar. Ege'de yoğunluklu olarak karaçam, Akdeniz bölgesinde ise, Toroslar kuşağında saf ve karışık sedir, göknar ve karaçam ormanları gelişir. İkinci kümenin yayılış gösterdiği güneydoğu Anadolu'da orman türü dağılışı meşe ağırlıklıdır. Ayrıca ardıç, karaçam ve kızılçam da yer alır. Küme 3, Türkiye'nin kuzeydoğusunda yüksek dağlık bir alanı temsil eder. Bu kümenin yayılış gösterdiği alanda sarıçam oranları karakteristiktir, ayrıca meşeler de görülür. Dördüncü küme en geniş yayılışa sahip biyoiklim bölgesi olarak Karadeniz
Ardı Bölge, İç batı Anadolu, İç Anadolu'yu kapsar. Meşe, karaçam ve kuzeydoğuya doğru sarıçamlar görülür. Orman formasyonu dağılışında ağırlıklı olarak karaçam dikkat çekmektedir. Bunlar dışında Orta Toroslar hattı boyunca ardıç, güneyde karışık meşe ve ardıç ormanları görülmektedir. Beşinci kümenin yayılış alanı ağırlıklı olarak Marmara Bölgesi ve Batı Anadolu'da iç kısımlarını kaplamaktadır. Bu kümenin baskın ağaç formasyonu meşe türleri olmakla birlikte, Trakya'da Istranca Dağları bölgesinde kayın ve Güney Marmara'da kızılçam ormanları da yer alır. Altıncı kümenin yayılış alanı olan Türkiye'nin kuzeyinde Karadeniz Bölgesi boyunca, çeşitliliğin yüksek olduğu bir orman örtüsü söz konusudur. Bu kümenin nemli kıyı kuşağında kayın, kızılçam, sarıçam, ladin karışık orman grupları oluşturur. iç kısımlara doğru artan karasallık etkisiyle karaçam ormanları yaygın olarak görülür.

\section{Değerlendirme ve Sonuç}

Bu çalışmada 169 istasyona ait 1960-2016 yılları arasında kaydedilen yağış ve sıcaklık verileri önce biyoiklim indislerine göre düzenlenmiş, elde edilen yeni serilere daha sonra Kümeleme Analizi uygulanmıştır. 3 farklı veri setinden yapılan analizler sonucunda:

- Kümeleme Analizinde sıcaklık için 4 küme elde edildi. Birinci küme kuzey ve güney kıyı bölgelerinde, ikinci küme Güneydoğu Anadolu'da, üçüncü küme Doğu Anadolu'da, dördüncü küme İç Anadolu ve Marmara Bölgesi başta olmak üzere geniş bir alanda dağılış göstermiştir.

- Yağış parametrelerine uygulanan analiz sonucunda 5 küme elde edildi. Birinci küme Ege, Akdeniz kıyılarında ve Güneydoğu Anadolu Bölgesi'nde, ikinci küme iç kısımlarda geniş alanda dağılış göstermekte, üçüncü küme Akdeniz Bölgesi'nde Kaş, Antalya, Alanya ve Gazipaşa istasyonlarının bulunduğu küçük bir bölgede, dördüncü küme Karadeniz Kıyı Bölgesi'nde ve Marmara'da, beşinci küme Rize ve Hopa istasyonunun olduğu bölgede dağılış göstermiştir.

- Tüm biyoiklim indisleri için uygulanan Kümeleme Analizinde alt küme elde edildi. Birinci küme Ege ve Akdeniz kıyı alanlarında, ikinci küme Güneydoğu Anadolu Bölgesi'nde, üçüncü küme Doğu Anadolu Bölgesi'nin yüksek plato alanlarında, dördüncü küme İç Anadolu Bölgesi'nde geniş bir alanda, beşinci küme Marmara Bölgesi ve Karadeniz Bölgesi'nde Bafra ve Artvin istasyonlarında ve altıncı küme Karadeniz Kıyı Bölgesi'nde dağılış göstermiştir.

Bı01-19 sınıflandırmasının sonucunda, Türkiye için tanımlanan biyoiklim tipleri ise; kuraklık ve soğuk mevsimde görece yüksek sıcaklıklar ile öne çıkan Küme 1; güneydoğuda dağılış gösteren ve kurak karakter ile tanımlanan Küme 2; kuzeydoğu-doğu kesimlerde hakim olan ve öne çıkan özelliği soğuk / nemli karakter olan Küme 3; yine kuraklıkla tanımlanan ama daha soğuk kış karakterinde olan, iç bölgelerde geniş alana yayılmış ve en fazla istasyon sayısına sahip Küme 4; kabaca Marmara Bölgesi sınırlarında dağılışa sahip, biyoiklim karakteri olarak da Karasal (küme 4) ve nemli (küme 6) arasında geçiş gösteren Küme 5 ve son olarak da nemlilik özelliği ile karakterize edilebilen ve Karadeniz kıyı kuşağı boyunca dağılış sergileyen Küme 6. Biyoiklim indislerinin (BIO1-19) mekansal dağılımı, önceki çalışmalarda belirlenen çeşitli sınıflandırmaların alansal değişkenlik örüntüsü ile oldukça uyumludur. Küme- 
leme analizinden elde edilen bölgesel dağılımın nedenlerine ilişkin klimatolojik yorumlamanın, bitki örtüsü dağılışında ön plana çıkan iklimsel özellikleri tanımlamak ve doğrudan sayısal değerler ile karşılaştırmalı olarak veri sunmak açısından literatüre katkı sağladığı ifade edilebilir.

Türkiye; Akdeniz, İran-Turan ve Avrupa-Sibirya kuşaklarına ait türlerin bir arada bulunduğu bir konumdadır ve doğal bitki örtüsü bakımından oldukça zengin bir biyoçeşitliliğe sahiptir. Türkiye 12.000 civarındaki bitki taksonu ve bunun içerisindeki 3/1'lik endemik oranı ile Dünya'da değişkenlik gösteren ekolojik şartlara sahip önemli ülkelerden biridir (Şenkul \& Kaya, 2017). Türkiye'de biyoiklimsel farklılaşmayı etkileyen en önemli etkenler arasında enlem, topografya ve iklim gösterilebilir. İndeks bazlı çalışmalar toprak, rakım, nem gibi diğer itici faktörleri temsil eden girdiler artırılarak güçlendirilmesi gerektiğinden, çalışma gelecekteki biyoiklim sınıflandırma çaIışmaları için bir temel oluşturabilir. Özellikle iklim değişikliği ve Türkiye'nin hızla değişen arazi örtüsü göz önüne alındığında; bitki örtüsü-iklim ilişkisini analiz etmek, sıcak noktaların belirlenmesi ve ekosistemler üzerindeki baskıların anlaşıması açısından çok önemlidir.

\section{Teşekkür ve Anma}

Tarım ve Orman Bakanlığı Meteoroloji Genel Müdürlüğü'ne veri temini için teşekkür ederiz. Türk Coğrafya Dergisi'nin bu sayısını, 21 Ocak 2021 tarihinde kaybettiğimiz Prof. Dr. Telat KOÇ'un anısına yayınlayan Editör Kurula teşekkür ederiz. Öğrencileri olarak, Telat hocamızı saygı ve özlemle anıyoruz.

\section{Kaynakça}

Akman, Y. (1990). Iklim ve biyoiklim. Palme Yayın Dağıtım.

Amigo, J., \& Ramírez, C. (1998). A Bioclimatic classification of chile: Woodland communities in the temperate zone. Plant Ecology, (136), 9-26. https://doi.org/10.1023/A:1009714201917

Atasoy, F. (2018). Türkiye'de Biyoklimatik Bölgelerin Mekansal Analiz Yöntemleriyle Sınıflandırılması (Yayın no: 523642) [Yüksek linsans tezi, Çanakkale Onsekiz Mart Üniversitesi Sosyal Bilimler Enstitüsü]. YüksekÖğretim Kurulu Başkanlığı Tez Merkezi.

Avcı, M. (1993). Türkiye'nin flora bölgeleri ve Anadolu Diagonali'ne coğrafi bir yaklaşım. Türk Coğrafya Dergisi, (28), 225-248.

Avcı, M. (2005). Çeşitlilik ve endemizm açısından Türkiye'nin bitki örtüsü. Coğrafya Dergisi,(13), 27-55.

Aydeniz, A. (1988). Aydeniz metodu ile Türkiye'nin kuraklık değerlendirilmesi, DMi Zirai Meteoroloji ve İklim Rasatları Dairesi Başkanlığı, Ankara.

Bölük, E. (2016). Aydeniz iklim sınıflandırmasına göre Türkiye iklimi. Meteoroloji Genel Müdürlüğü. Ankara.

Çakan, H., \& Byfield, A. (2005). Türkiye'nin 122 önemli bitki alanı. Amanos Dağları. WWF Türkiye Doğal Hayat Koruma Derneği Vakfi Yayını.

DeGaetano, A.T., \& Shulman, M.D. (1990). A climatic classification of plant hardiness in the United States and Canada. Agricultural and Forest Meteorology, (51), 333-351. https://doi.or$\mathrm{g} / 10.1016 / 0168-1923(90) 90117-0$

Erinç, S. (1984). Klimatoloji ve metot/arı. İstanbul Üniversitesi Deniz Bilimleri ve Coğrafya Enstitüsü, İstanbul.

Evrendilek, E., \& Berberoğlu, S. (2008). Quantifying spatial patterns of bioclimatic zones and controls in Turkey. Theoretical and Applied Climatology, (91), 35-50. https://doi.org/10.1007/s00704006-0294-9
Griffith, D.A., \& Amrhein, C.G. (1997). Multivariate statistics for geographers. Prentice-Hall,

Günal, N. (2013). Türkiye'de iklimin doğal bitki örtüsü üzerine etkileri. Acta Turcica, (1), 1-22.

Hair, J.F., Anderson, R.E., \& Tatham, R.L. (1995). Multivariate data analysis. Prentice Hall Inc.

Macías-Rodríguez, M., Peinado, M., Giménez de Azcárate, J., Aguirre, J., \& Delgadillo, J. (2014). Clasificación bioclimática de la vertiente del Pacífico mexicano relación con la vegetación potencial. Acta Botanica, (109), 133-165. https://doi.org/10.21829/ abm109.2014.194

Miller, W.S. (1973). Factor analytic models of bioclimatic relations for canadian forest regions. Department of Biology McGill University.

Orlov M., \& Sheludkov A. (2019) Bioclimatic data optimization for spatial distribution models. In: Bychkov I., \& Voronin V. (eds) Information Technologies in the Research of Biodiversity. Springer Proceedings in Earth and Environmental Sciences. Springer, Cham. https://doi.org/10.1007/978-3-030-11720-7 13

Öztürk, M.Z., Çetinkaya, G., \& Aydın, S. (2017). Köppen-Geiger iklim sınıflandırmasına göre Türkiye'nin iklim tipleri. Journal of Geography, (35), 17-27. https://doi.org/10.26650/JGEOG295515

Pearson, R., \& Dawson, T. (2003). Predicting the impacts of climate change on the distribution of species: Are bioclimate envelope models useful? Environmental Change Institute. School of Geography and the Environment. University Of Oxford.

Pesaresi, S., Galdenzi, D., Biondi, E., \& Casavecchia, S. (2014). Bioclimate of Italy: Application of the worldwide bioclimate classification system. Journal of Maps, 10(4), 538-553, https://doi.org/10 $.1080 / 17445647.2014 .891472$

Sarış, F., Hannah, D., \& Eastwood, W. (2010). Spatial variability of precipitation regimes over Turkey. Hydrological Sciences Journal, (55), 234 - 249. https://doi.org/10.1080/02626660903546142

Şenkul, Ç., \& Kaya, S. (2017). Türkiye'de endemik bitkilerin coğrafi dağılışı. Türk Coğrafya Dergisi, (69), 109-120. https://doi. org/10.17211/tcd.322515

USGS. (2012). Bioclimatic predictors for supporting ecological applications in the conterminous United States. United States: U.S. Geological Survey Data Series 691, 10 P.

Unal, Y.S., Kındap, T., \& Karaca, M. (2003). Redefining the climate zones of Turkey using cluster analysis. International Journal of Climatology, 23, 1045-1055. https://doi.org/10.1002/joc.910

Vogel, K.P., Schmer, M.R., \& Mitchell, R.B., (2005). Plant adaptation regions: Ecological and climatic classification of plant materials. U.S. Department Of Agriculture: Agricultural Research Service.

Yaghmaei, L., Soltani, S., \& Khodagholi, M. (2009). Bioclimatic classification of Isfahan province using multivariate statistical methods. International Journal of Climatology, (29), 1850-1861. https://doi.org/10.1002/joc.1835

Yılmaz, E., \& Çiçek, i. (2016). Türkiye Thornthwaite iklim sınıflandırması. Uluslararası Insan Bilimleri Dergisi, 13(3), 3973-3994. https://doi.org/10.14687/ihs.v13i3.3994

Yılmaz, E., \& Çiçek, i. (2018). Türkiye'nin detaylandırılmış Köppen-Geiger iklim bölgeleri. Uluslararası Insan Bilimleri Dergisi, 15(1), 225-242. https://doi.org/10.14687/ihs.v15i1.5040

Tuğay, M.E., \& Akdağ, C. (1989). Türkiye iklim ve tarım bölgeleri. Sivas Yöresinde Tarımın Geliştirilmesi Sempozyumu. 30 Mayıs-3 Haziran, Sivas.

Walter, H., 1970. Vegetationszonen and Klima. E. Ulmer, Stuttgart. 